Volume 5 Number 2, July-December 2021: pg. 141-154.

Fakultas Hukum, Universitas Lampung,

Bandar Lampung, Lampung, Indonesia.

E-ISSN: 2598-3105 P-ISSN: 2723-2581

http://jurnal.fh.unila.ac.id/index.php/cepalo

\title{
CHILD ADOPTION BY UNMARRIED PERSON IN THE INDONESIAN CIVIL LAW SYSTEM
}

\author{
Glad Mauraina ${ }^{1}$, Angel Pratiwi², Dian Purnama ${ }^{3}$ \\ ${ }^{1}$ Faculty of Law, Universitas Airlangga, Indonesia, \\ Email: glad.mauraina-2020@fh.unair.ac.id \\ ${ }^{2}$ Faculty of Law, Universitas Airlangga, Indonesia, \\ Email: angel.pratiwi-2020@fh.unair.ac.id \\ ${ }^{3}$ Faculty of Law, Universitas Airlangga, Indonesia, \\ Email: dian.purnama-2020@fh.unair.ac.id
}

Submitted: July 21, 2021; Reviewed: October 23, 2021; Accepted: October 29, 2021

DOI: 10.25041/cepalo.v5no2.2390

\begin{abstract}
Adoption is carried out by a legally married couple and could also be done by someone who does not want to build a household but still wants to have children as successors and who would take care of them in the future as a single parent. Article 10 paragraph (3) of the Regulation of the Minister of Social Affairs of the Republic of Indonesia Number 110/HUK/2009 concerning Child Adoption Requirements states that child adoption through a childcare institution could be carried out firstly by a prospective foster parent. Prospective Foster Parents have been legally married for a minimum of five years, as stated in Article 20 letter e of the Regulation of the Minister of Social Affairs of the Republic of Indonesia Number 110/HUK/2009. In this research journal, we would discuss the issue of Child Adoption by Non-Marriage Person. This study focuses on normative legal research that examines the content of legislation. This legal research was conducted with two approaches consisting of a statutory approach and a conceptual approach. Researchers would find ideas that provide legal understanding, legal concepts, and legal principles. This research concludes that adoption could be carried out by married couples and non-married person/single parent. It is referred to Government Regulation Number 54 of 2007 concerning Adoption of Children. This regulation is reinforced by the issuance of Circular Letter of the Supreme Court (SEMA) Number 6 of 1983 explaining that it is possible for Indonesian citizens who are unmarried, have been married, or a single parent, to adopt a child.
\end{abstract}

Keywords: Adoption, Unmarried Person, Single Parent.

\section{A. Introduction}

Humans are the perfect creatures compared to others because there are 5 (five) significant events in their life: birth, recognition (of birth), marriage and divorce, death, and permission to 
marry. ${ }^{1}$ Humans are also referred to as social beings because they could not survive without the company of other humans. As a result, God Almighty created humans in pairs, male and female, to live in this world. This is under the provisions of Article 1 of Law Number 1 of 1974 concerning Marriage (further in this journal referred to as the Marriage Law), which states that marriage is a physical and spiritual bond between a man and a woman as husband and wife to form a family (household) happily and eternal based on the One and Only God. Based on the provisions of Article 2 of the Marriage Law, a husband and wife could build a happy household if they have carried out a legal marriage according to their respective religions and beliefs and are registered by law.

One of the rights guaranteed by the 1945 Constitution is the right to marry and have children. ${ }^{2}$ Marriage is the beginning of a family. Its purpose is to meet biological needs. The Marriage Law defines the ideal or perfect family element consists of the father, mother, and children. The majority of married couples prefer to have children in their families. ${ }^{3}$ Some husbands and wives go to great lengths to have children to achieve this ideal and perfect family. ${ }^{4}$ There are three paths to becoming a legally recognised parent: biological kinship, marriage, and adoption. ${ }^{5}$ However, it is not always possible. This could be attributed to various factors, including health, age, and personal decisions not to marry. There are other options for a person or a married couple to have children, such as adoption, governed by Indonesian law. Adoption could be done for a variety of reasons, including: ${ }^{6}$

1. There are no children in the family, and there is a desire to have their children to secure their future and old age;

2. To maintain the marriage or family happiness;

3. The belief that the presence of children would cause them to be able to have their biological children;

4. A sense of concern for abandoned children or children with parents who are unable to raise them;

5. To get a job.

Indonesia's Government strongly supports child adoption because children have the right to be protected legally and have a decent life for their future. This protection is a human right guaranteed by Pancasila, as in the Constitution of the Republic of Indonesia in Article $28 \mathrm{~B}$ of the 1945 Constitution of the Republic of Indonesia and legislation, including in Article 59 of Law Number 35 of 2014 concerning Amendments to the Law Number 23 of 2002 concerning Child Protection. ${ }^{7}$ However, adoption laws require a highly individualised examination of what is in the best interests of each child for whom adoptive parents are sought. ${ }^{8}$ Child adoption has

\footnotetext{
${ }^{1}$ R. Soetojo Prawirohamidjojo and Marthalena Pohan, Hukum Orang Dan Keluarga (Personen En Familie-Recht) (Surabaya: Airlangga University Press, 2008): 5-6.

${ }^{2}$ Rudyanti Dorotea Tobing, "Prevention of Child Marriage Age in the Perspective of Human Rights," Sriwijaya Law Review 2, no. 1 (2018): 1-17, https://doi.org/10.28946/slrev.Vol2.Iss1.107.pp1-17.

${ }^{3}$ Yolanda Triana Siregar and Meilanny Budiarti Santoso, “Adopsi Dalam Perspektif Pekerjaan Sosial,” Kumawula: Jurnal Pengabdian Kepada Masyarakat 1, no. 3 (2018): 202-18, https://doi.org/10.24198/kumawula.v1i3. 22676. ${ }^{4}$ Fransiska Maryl Agatha, I Ketut Widia, and I Ketut Sukadana, "Pengangkatan Anak Oleh Orang Tua Yang Berbeda Keyakinan Dengan Calon Anak Angkatnya," Jurnal Prefensi Hukum 1, no. 2 (2020): 16-20, https://doi.org/10.22225/jph.1.2.2391.16-20.

5 Samantha Bei-wen Lee, "The Equal Right to Parent: Protecting the Rights of Gay and Lesbian, Poor, and Unmarried Parents," NYU Review of Law and Social Change 41, no. 4 (2018): 631-84, https://socialchangenyu.com/review/the-equal-right-to-parent-protecting-the-rights-of-gay-and-lesbian-poor-andunmarried-parents/.

${ }^{6}$ Siregar and Santoso, "Adopsi Dalam Perspektif Pekerjaan Sosial."

${ }^{7}$ Islamia Ayu Anindia, "Perlindungan Hukum Terhadap Perdagangan Anak Dengan Modus Pernikahan Dalam Perspektif Viktimologis," Jurnal Litigasi 19, no. 1 (2018): 89-115, https://doi.org/10.23969/litigasi.v19i1.776.

${ }^{8}$ Mark Simpson, "Social Rights, Child Rights, Discrimination and Devolution: Untangling the Web," Journal of Social Welfare and Family Law 40, no. 1 (2018): 3-20, https://doi.org/10.1080/09649069.2018.1414201.
} 
become a community need in Indonesia. It is part of the family law system. Therefore the institution of child adoption has become part of the community and would follow the development of the situation and conditions. ${ }^{9}$

According to Arif Gosita, the definition of adoption is an act of taking another person's child to be cared for and treated as their child based on mutually agreed provisions and legally according to the relevant law. The term adoption comes from adoptie (Dutch), which means adopting a child. ${ }^{10}$ Based on the etymological understanding, it emphasises that the status of adopted children is the same as that of biological children. In contrast, some experts believe that they focus more on adoption by not giving the same status as the definition of biological children based on terminology. There are various backgrounds and purposes of doing adoption. In general, adoption is carried out to fulfil the interests of the adoptive parent, to continue the descent, especially if they are unable to have children. Another purpose is the child's future interest in being adopted because the adopted children come from neglected children or the parent's economic situation who could not support them. In today's practice, adoption is carried out by a married couple and could also be done by someone who does not want to build a household but still wants to have children as heirs and would care for them as a single parent in the future.

Based on Article 9 of the Regulation of the Minister of Social Affairs of the Republic of Indonesia Number 110/HUK/2009 concerning Requirements for Adoption of Children, it is stated that child adoption consists of adoption between Indonesian Citizens and between Indonesian Citizens and Foreign Citizens. Article 10 paragraph (3) of the Regulation of the Minister of Social Affairs of the Republic of Indonesia Number 110/HUK/2009 concerning Child Adoption Requirements states that child adoption through a childcare institution could be carried out by a prospective foster parent, including a foreign citizen or by a single parent. Private adoption of children could be carried out by Prospective Foster Parents who are legally married for a minimum of five years, as stated in Article 20 letter e of the Regulation of the Minister of Social Affairs of the Republic of Indonesia Number 110/HUK/2009. In that case, child adoption could also be carried out by people who are not married.

In this research journal, we would discuss the issue of the adoption of Children by NonMarriage Person. There are two different points of view regarding child adoption laws and regulations in Indonesia. This study focuses on normative legal research that examines the content of legislation. This legal research was conducted with two approaches consisting of a statutory approach and a conceptual approach. The statutory approach is implemented by reviewing all laws and regulations related to handling legal issues. The conceptual approach is implemented by studying the views and doctrines in legal research. Researchers would discover ideas that provide legal understanding, legal concepts, and legal principles.

\section{B. Discussion}

\section{Scope And Definition of Child Adoption}

Children are not only gifts given by God but also a mandate. Therefore, parents and families require protection to grow and develop, but not all children receive this. On the other hand, many families do not have children and desperately want children through adoption. ${ }^{11}$ This

\footnotetext{
${ }^{9}$ Haedah Faradz, "Pengangkatan Anak Menurut Hukum Islam,” Jurnal Dinamika Hukum 9, no. 2 (2009): 15359, https://doi.org/10.20884/1.jdh.2009.9.2.223.

10 Trisadini Prasastinah Usanti and Ghansham Anand, Hukum Keluarga Dan Harta Benda Perkawinan (Surabaya: CV Revka Prima Media, 2019): 159.

${ }^{11}$ Leonora Bakarbessy and Dian Purnama Anugerah, "Implementation of the Best Interests of the Child Principles in Intercountry Adoption in Indonesia," Yuridika 33, no. 1 (2018): 73-92, https://doi.org/10.20473/ydk.v33i1.7202.
} 
adopting issue is interesting because it is always close during society, which turns out not only in the present but has existed in people's lives since pre-colonial times. ${ }^{12}$ Adoption was previously better known to help married couples who had not been blessed with children, so it could be concluded that adoption is an alternative way to save marriage because one of the goals of marriage is to have children. However, according to recent developments, child adoption could be carried out by someone who is not married but still wants to adopt.

The child's adoption is aimed at the parents who adopt a child and other objectives in Article 2 of Government Regulation Number 54 of 2007 concerning the Implementation of Child Adoption. This Article state, "The child's adoption is aimed at the best interests of the child in the context of realising child welfare and child protection, which is carried out based on local customs and provisions of laws and regulations". These laws are specifically enacted to protect a child's best interests. ${ }^{13}$ The definition of adoption could be found in Article 1 paragraph (2) of Government Regulation Number 54 of 2007 concerning Child Adoption, which states that "adoption is a legal act that diverts a child from the environment of parental authority, legal guardian, or another person who is responsible the care, education, and rearing of the child, into the family environment of the adoptive parents".

\section{a. Type/ Kinds of Adoption}

Adoption of children based on positive law in Indonesia, there are various kinds of child adoption whose provisions could be found in Article 7 of Government Regulation Number 54 of 2007 concerning Child Adoption, consisting of:

1) Adoption of children among Indonesian citizens, including:

a) Adoption of children based on local customs; and

b) Adoption of children based on the laws and regulations.

2) Adoption of children between Indonesian citizens and foreign citizens, including:

a) Adoption of children of Indonesian citizens by foreign citizens; and

b) Adoption of children of foreign citizens in Indonesia by foreign citizens.

Adopting children based on customs and statutory regulations could be done through stipulation from the court. In contrast, the adoption of children between Indonesian citizens and foreign citizens should be done through court decisions.

There are two types of child adoption based on the laws and regulations, namely:

1) Private Adoption

Conducted by prospective adoptive parents carry out direct adoption with prospective adopted children who are still directly under the supervision of their biological parents.

2) Agency Adoption

Conducted by prospective adoptive parents with prospective adopted children appointed by the minister.

Adopting a child based on this statutory regulation should be applied with a stipulation from the court at the local District Court. However, after the issuance of Law Number 3 of 2006 in the elucidation of Article 49 letter a number 20, it is explained that the religious court has the authority to issue decisions related to the adoption of children, especially the adoption children who are carried out by people who follow the Islamic religion. ${ }^{14}$

\footnotetext{
${ }^{12}$ M. Fahmi Al Amruzi, “Anak Angkat Di Persimpangan Hukum,” Masalah-Masalah Hukum 43, no. 1 (2014): 107-14, https://doi.org/10.14710/mmh.43.1.2014.107-114.

${ }^{13}$ Ibrahim Danjuma and Karatu Afabwaje Joel, "The Legal Conundrum in the Implementation of the Conventionon on the Rights of the Child in Nigeria," Sriwijaya Law Review 5, no. 1 (2021): 1-13, https://doi.org/10.28946/slrev.Vol5.Iss1.603.pp1-13.

${ }^{14}$ Usanti and Anand, Hukum Keluarga Dan Harta Benda Perkawinan.
} 


\section{b. Adoption by Single Parent}

Adoption of a child when referring to the provisions of Article 13 letter e of Government Regulation Number 54 of 2007 concerning Child Adoption which states that: "Prospective adoptive parents should meet requirements such as married status of at least 5 (five) years." So based on this provision, adoptive parents should have married status. Still, there are exceptions to this provision, which could be found in the following provision in Article 16 paragraph (1): "Adoption of a child by a single parent could only be carried out by Indonesian citizens after obtaining permission from the Minister". Furthermore, Article 16 paragraph (2) the granting of permits as referred to in paragraph (1) could be delegated to the province's head of the social agency. Based on these provisions, a single parent may adopt a child if they obtain permission from the Minister of Social Affairs. The permit is delegated to the Provincial Head of Social Agencies and a court stipulation. In addition, based on the Circular Letter of the Supreme Court (SEMA) Number 6 of 1983 explains that a single parent and an Indonesian citizen could adopt a child. Thus, this single parent could be allowed to adopt a child, as long as it could be proven that the child's welfare could be fulfilled in terms of physical, spiritual, and social needs as mandated in Law Number 4 of 1979 concerning Child Welfare.

Adopting a child requires permission from the Minister of Social Affairs and the parties involved in the adoption process because many children's rights have not been adequately fulfilled, physically, mentally, spiritually, or socially. This happens because of mistakes made by irresponsible adults or parents, so that children who know nothing should accept and become the impact of the actions and omissions of those irresponsible people. Thus, the law's existence plays a role in social life and functions as an interaction regulator between humans to regulate what should be done and what could and could not be done. In this case, the law could also function as a driver of development; it could bring a better society. ${ }^{15}$ Considering that law should be accommodating to the development of the demands of the times so that the community's need for the governing law could be fulfilled and the realisation of legal objectives, namely legal certainty and legal benefits.

The definition of the single parent is regulated in the general provisions of Article 1 point 5 of the Regulation of the Minister of Social Affairs of the Republic of Indonesia Number 110/HUK/2009 concerning Requirements for Adoption of Children which states that: "In this regulation, the single parent is unmarried or widowed/widower." The Minister of Social Affairs regulation is further regulation of the Government Regulation on Adoption of Children, which regulates the adoption of children by a single parent. It is not uncommon to find single parent carrying out that child adoption in today's practice. It is expected to play a role through legislation to accommodate all societal developments to drive development.

Adoption of children carried out by married couples and the single parent should also consider the provisions of Article 1 to Article 16 of Law Number 4 of 1979 concerning Child Welfare, which includes the child's rights and parental responsibilities for the welfare of the child. The efforts that should be made in realising the child's welfare aim to ensure the fulfilment of the child's basic needs, given the background of the adoption of children related to the child's interests. Every child has a future, and as the next generation, that needs to get the broadest opportunity to grow and develop spiritually, physically and socially. Child welfare is a way of life and livelihood of children that could ensure proper growth and development, both spiritually, physically, and socially. The preceding points apply to biological and adopted children because both should get the same rights and treatment. There should be no difference in treatment in any aspect, including getting a proper and good life. Adoption should not become a bad start for the child's life and neglect later on.

15 Didiek R. Mawardi, "Fungsi Hukum Dalam Kehidupan Masyarakat," Masalah-Masalah Hukum 44, no. 3 (2015): 275-83, https://doi.org/10.14710/mmh.44.3.2015.275-283. 


\section{The Process of Child Adoption by Single Parent}

Child adoption should not be done arbitrarily and should comply with the procedures prescribed by legislation and the Department of Population and Civil Registration. Adoption could only be carried out in the child's best interest and could be carried out following the applicable laws and regulations. However, it could also be carried out following the provisions in force in the customs prevailing in their respective regions. Adopting a child would get legal legality if carried out legally according to law. The prospective adoptive parents should adhere to the same religious beliefs as the prospective child. If the child's origin is unknown, the child's religion is adapted to most of the population where the child is discovered. Article 15 paragraph (2) of the Staatsblad (Stb) 1917 No. 129 states that the adoption of daughters and the adoption by other than by making an authentic deed are null and void. This provision departs from the belief system in the Chinese that it is a boy who could continue the lineage. Nevertheless, the existence of jurisprudence in the 1962 Jakarta Special District Court Decision amended this provision. The provisions in 1917, Staatsblad No. 129, were changed to allow girls' adoption. The child's adoption could not be terminated by agreement or at the parties' will, but only by law for the reasons stated in Article 15 paragraph (3) Stb. 1917 No. 129.

Regulations regarding the adoption of children by a single parent in Indonesia could be found that it has not been specifically regulated. The special provisions are still scattered in several regulations such as SEMA Number 6 of 1983, Government Regulation Number 54 of 2007, Regulation of the Minister of Social Affairs Number 110/HUK/2009, and general regulations are explicitly implied in several laws that accommodate issues regarding children, such as Law Number 23 of 2002 concerning Child Protection, Law Number 4 of 1979 concerning Child Welfare and others. ${ }^{16}$ The provisions of Article 16 of Government Regulation Number 54 of 2007 concerning the Implementation of Child Adoption state that to adopt a child by a single parent, among other things, should meet:

a. Adopting children by a single parent could only be carried out by Indonesian citizens after obtaining permission from the Minister of Social Affairs.

b. As mentioned in paragraph (1), the given permit could be delegated to the province's head of the social agency.

In the adoption process, not only should comply with the provisions of Article 16 of Government Regulation Number 54 of 2007 but should also comply with the provisions of Article 4 to Article 6 of the Regulation of the Minister of Social Affairs of the Republic of Indonesia Number 110/HUK/2009 concerning Requirements for Child Adoption. Child adoption should meet the material requirements of prospective children who could be adopted, including:

a. Children who are under 18 (eighteen);

b. Is an abandoned or being neglected child;

c. Being in family care or a Childcare Institution; and

d. Requires special protection.

Article 5 explains that the adoption application should also attach the administrative requirements of the Prospective Adopted Child, which includes:

a. Photocopy of ID card of biological parents/legal guardians/Prospective Adopted Child relatives

b. Photocopy of Prospective Adopted Child parents' family card; and

c. Birth certificate quotation of Prospective Adopted Child.

\footnotetext{
16 Dessy Marliani Listianingsih, Surini Mangundihardjo, and Farida Prihatini, "Urgensi Pengaturan Terhadap Pengangkatan Anak Oleh Orang Tua Tunggal (Single Parents Adoption: Studi Kasus Penetapan No. 1/PDT.P/2010.PN.KGN Dan Penetapan No. 180/PDT.P/2012/PN.DPK," Jurnal Hukum Acara Perdata 6, no. 1 (2020): 17-34, https://doi.org/10.36913/jhaper.v6i1.99.
} 
Article 6 explains the Prospective Adopted Child Requirements as referred to in Article 4 letter a, divided into 3 (three) categories, which include:

a. Children under 6 (six) years old are the main priority, including children who are neglected, children in urgent situations, and children who need special protection;

b. Children aged 6 (six) years up to under 12 (twelve) years as long as there is an urgent reason based on social reports, namely abandoned children who are in an emergency;

c. Children aged 12 (twelve) years up to under 18 (eighteen) years is neglected children who need special protection.

Thus, it could be seen that after fulfilling the material and administrative requirements, the application is submitted to the Child Care Institution for getting permission from the Minister of Social Affairs or the Head of the Provincial Social Agency. After obtaining permission, the permit should be submitted to the court by registering an adoption application to obtain a determination that could be used as legal evidence that the adopted child has been legally adopted by law. A decision from the court accompanies all the requirements described above. It should also be remembered that the adoption of this child would not break the blood relationship between the adopted child and his biological parents.

The adoption of children through the judiciary is carried out because considering that the act has legal consequences, so it is essential and related to obtaining legal certainty, legal protection, legal justice, legality, and legal documents for legal acts of adoption. According to the law, legal documents stating that the adoption has been carried out are essential in family law because the legal consequences of adoption would affect several generations of descendants concerning inheritance law, legal responsibilities, and others.

The state's recognition would provide legal protection for a child by authorising birth certificates to be biological and adopted children. However, an adopted child would need a court order to recognise his legal status. Based on Article 47 of Law Number 23 of 2006 concerning Population Administration that in the registration of child adoption it is regulated as:

a. Registration of child adoption is carried out based on a court order at the applicant's place of residence.

b. The registration of child adoption referred to in paragraph (1) should be reported to the Implementing Agency that issues the Birth Certificate Quotation by the Resident no later than 30 (thirty) days after receiving a copy of the court order.

c. The Civil Registration Officer makes a marginal note on the Birth Certificate Register and Birth Certificate Quotation as referred to in paragraph (2).

Regarding the adoption process, the Supreme Court explained that preparing a birth certificate before the court's decision was granted is critical because the contents of the court order would be written as a side note in the birth certificate register. ${ }^{17} \mathrm{~A}$ birth certificate is authentic evidence of a child's origin and should be owned by everyone. However, there are cases where a child's origin and the identity and location of their parents are unknown, such as a baby disposed of in a trash can or ditch (sewer). Therefore, in the child's best interests, a decision could be made through the District Court or the Religious Court for a child adopted by a Muslim adoptive parent so that the child knows who is responsible as a caregiver or guardian.

The provisions of Article 27 paragraph (4) of Law Number 35 of 2014 concerning Amendments to Law Number 23 of 2002 concerning Child Protection stipulates that "In the case of a child whose birth process is unknown and the parents' whereabouts are unknown, birth certificate formation for the child is based on the information of the person who discovered it and is accompanied by an official police report". Furthermore, Article 33 paragraph (3) of

17 Mys and Ali, "Penetapan Adopsi Harus Disertai Akta Kelahiran Anak," HukumOnline.com, 2009, https://www.hukumonline.com/berita/baca/hol21746/penetapan-adopsi-harus-disertai-akta-kelahiran-anak. 
Government Regulation Number 96 of 2018 concerning Requirements and Procedures for Population Registration and Civil Registration states that "the registration of an Indonesian citizen's birth for a child whose origin or whereabouts are unknown other than with an official report from the police should fulfil the requirements for a statement of absolute responsibility for the truth of birth data with 2 (two) witnesses."

\section{Legal Consequences of Child Adoption by Single Parent}

Adoption aims to give the same status or position as biological children to other people's children. However, many deviations occur in society regarding the implementation of child adoption. Adoption is mainly done by falsifying data, without going through the proper procedures, child trafficking, which even occurs buying and selling children's organs. ${ }^{18}$ Even in adopting children, it is known that adopted children are more likely to contact mental health institutions. Data from the 2003 American National Survey of Children's Health stated a significant increase in particular health care needs, learning disabilities, developmental delays and other mental health difficulties in the adopted group compared to non-adopted children. It could be concluded that this reflects a difference in clinically significant problems when compared with non-adopted children, even in a study conducted in 2013 showing an increase in the number of suicide attempts of adopted children. ${ }^{19}$ The legal protection given to adopted children includes several aspects, which also refer to the child's human rights that exist in the child, including protection against religion, health, education, social rights, and the protection of particular importance/exceptional. ${ }^{20}$

Adopting a child does not result in the severance of the blood relationship between the adopted child and his biological parents. This follows Article 39 paragraph (2) of Law Number 35 of 2014 concerning Amendments to Law Number 23 of 2002 concerning Child Protection. Thus the adopted child still has an unbreakable relationship by blood relations. Adoption has legal consequences, so there is an obligation to be registered in the birth certificate without eliminating the child's identity. In contrast, the child's adoption impacts the legal relationship's disappearance between the adopted child and their original parents and all family members by blood and by the marriage of the original parents. However, there are exceptions to the abolition of the legal relationship when it comes to:

a. the degree of kinship by blood and marriage is prohibited from marrying,

b. the criminal provisions merely rely on the descent due to birth,

c. the calculation of costs and hostages,

d. evidence and witnesses, and

e. acts as a witness in performing authentic deeds.

The position adopted legal child of his adoptive parents. Therefore, there is also a relationship with all family members by blood and adoptive parents' marriage. As a legitimate child, the adopted child is considered born from the marriage that adopted them, if the one who made the adoption is a husband and wife couple. The adoption of this child creates a legal relationship between the adoptive parents and their adopted child. The relationship is like the relationship between parents and legitimate children so that adoptive parents have the authority as parents over their adopted children. There is a relationship between civil rights related to

\footnotetext{
${ }^{18}$ Condro Putri Dewi Hartaka, “Akibat Hukum Dalam Pewarisan Dari Pelaksanaan Pengangkatan Anak Oleh Orang Tua Tunggal,” Jurnal Preferensi Hukum 1, no. 2 (2020): 181-85, https://doi.org/10.22225/jph.1.2.2384.181-185.

19 Margaret DeJong, Jill Hodges, and Osman Malik, "Children After Adoption: Exploring Their Psychological Needs," Clinical Child Psychology and Psychiatry 21, no. $4 \quad$ (2015): 1-15, https://doi.org/10.1177/1359104515617519.

${ }^{20}$ H. Ahmad Kamil and H. M. Fauzan, Hukum Perlindungan Dan Pengangkatan Anak Di Indonesia, 1st ed. (Jakarta: PT RajaGrafindo Persada, 2008): 1-472.
} 
inheritance, adoptive parents and their adopted child, and an obligation of alimentation. The adoptive parents have the right of alimentation from their adopted child. In contrast, the biological parents' civil relationship with their adopted child would be severed, as would all of the adoption's consequences. The child is no longer under the authority of his original parent and the obligations arising from it, such as the relationship of civil rights to inheritance, including the right of alimentation of the child's parents and vice versa.

If the adopter is a widower, the child is considered born from a marriage ended by death. If the adopter is a widow, the child is considered born from marriage with her deceased husband. According to the provisions of Article 9 Stb. 1917 No. 129, the child is considered the husband's heir if the adoption is made within 6 (six) months after the widow's husband dies or within 6 (six) months the widow asks the court for permission to adopt a child. Another situation is when the adoption is made within a grace period of one month after the permit is obtained. In the provisions of Article 12 Stb. 1917 No. 129, with the adoption of a child, then the adopted child uses the surname of his adoptive parents and has the same legal status as the biological child of his adoptive parents. The legal consequences of adopting a child based on S. 1927 No. 129, are: a. The adopted child legally obtains the name of the adoptive father (Article 11);

b. Adopted child become a child born from the marriage of adoptive parents (Article 12 paragraph (1));

c. The adopted child becomes the heir of the adoptive parents;

d. Because of the adoption, all civil relations originating in offspring due to birth are cut off (child with biological parents) Article 14.

There are some rights and obligations between adoptive parents and adoptive children that each party should carry out. Children's rights are regulated in Law Number 4 of 1979, while their obligations are regulated in Law Number 23 of 2002. The adoptive child also has rights in inheritance law, which are having the right and obligations as heirs, both materially and immaterially. The adoptive parents also have rights and obligations; even they have responsibilities as parents. Adoptive parents' rights change along with the transition of authority from birth to adoptive parents. The adoptive parents are responsible for the child. The parental authority of the adoptive parents applies to the adopted child. It would end when the child becomes an adult or married, or for some reason, the authority of the adoptive parent is released or revoked by the judge.

The obligations and responsibilities of parents are stated in Law Number 35 of 2014. The arrangements regarding the obligations of adoptive parents or single parent who adopt children against adopted children are the same as parents and children in general. Adoptive parents are obliged to explain their origins and biological parents to their adopted children, whose obligations are stated in Government Regulation Number 54 of 2007. The rights and obligations owed by the adoptive child and adoptive parents would lead to legal consequences because adopting a child is part of an intentionally carried out legal action. The legal consequences are reciprocity between the adoptive parents and the adopted child and the adoptive parents with the adopted child's biological parents.

Article 2 of Law Number 35 of 2014 concerning Amendments to Law Number 23 of 2002 concerning Child Protection stated that: "The implementation of child protection is based on Pancasila and the 1945 Constitution of the Republic of Indonesia and the basic principles of the Convention on the Rights of the Child that includes the principle of non-discrimination, the best interests of the child, the right to life, life sustainability and development as well as respect for children's rights". Every child has the right to be protected from discrimination, economic and 
sexual exploitation, neglect, cruelty, violence, persecution, injustice, and other mistreatment while caring for parents, guardians, or any other party responsible for the care. ${ }^{21}$

The regulation regarding the adoption of children is regulated in article 39 of the Child Protection Act. Essential things regarding the regulation of child adoption are that child adoption could only be carried out in the child's best interest and is carried out based on local customs and provisions of laws and regulations. Therefore, the adoption of a child is permitted in Article 16 paragraph (1) of Government Regulation Number 54 of 2007 concerning the Implementation of Child Adoption for the child's best interests. Hence, a single parent's adoption of a child is also an effort in the child's best interests to receive care, education and be raised in the family environment of the adoptive child's parents. People should be granted custody regardless of their backgrounds as long as the child could be cared for, educated, have parents, and feel loved by parents who have adopted a child. Therefore, this is one of the essential things in adopting a child that is carried out in the child's best interest. ${ }^{22}$ The Minister of Social Affairs Regulation Number 110/Huk/2009 and other laws and regulations state that the purpose of adopting a child is for the child's welfare by taking a note to the child's best interests. This intersects with single parent adoption, which a single parent only does.

Single Parent Adoption becomes an alternative because it is often considered beneficial to many parties, both for the adopted child and a single parent who wants children. In Indonesia, adoption by a single parent has not been specifically regulated. The special provisions are still scattered in several regulations such as Circular Letter of the Supreme Court or Surat Edaran Mahkamah Agung (SEMA) Number 6/1983, Government Regulation Number 54/2007, Regulation of the Minister of Social Affairs Number 110/HUK/2009, and regulations that are general explicitly implied in several laws that accommodate issues regarding children, such as Law Number 23 of 2002 concerning Child Protection, Law Number 4 of 1979 concerning Child Welfare and others. ${ }^{23}$ This is a negative perspective of adopting children by a single parent. Even in Indonesia, there is no separate law that specifically regulates the adoption of children. Child adoption has become a legal issue in Indonesia, necessitating legal unification.

There are two types of legal protection against adoption by a single parent, namely preventive legal protection and repressive legal protection. The government provides preventive legal protection in order to prevent violations from occurring. This is contained inlaws and regulations and provides signs or limitations in carrying out an obligation. Simultaneously, repressive legal protection is absolute protection in the form of sanctions such as fines, imprisonment, and additional penalties if it is violated. ${ }^{24}$

Preventive legal protection in child adoption by a single parent is regulated by Government Regulation Number 54 of 2007 concerning Child Adoption and Minister of Social Affairs Regulation Number 110/HUK/2009 concerning Child Adoption Requirements. Based on Article 13 letter $\mathrm{j}$ of Government Regulation Number 54 of 2007 concerning Adoption of Children in conjunction with Article 32 letter h of the Regulation of the Minister of Social Affairs Number 110/HUK/2009 concerning Requirements for Adoption of Children, prospective adoptive parents should meet required conditions. One of which is to state that

\footnotetext{
${ }^{21}$ Stanley Noer H and Mulati, “Analisis Terhadap Peraturan Pemerintah No. 54 Tahun 2007 Tentang Pelaksanaan Pengangkatan Anak Ditinjau Dari Prinsip Non Diskriminasi Dalam Konvensi Hak Anak (Contoh Kasus Polwan Gagal Adopsi Anak Karena Terhalang Peraturan Pemerintah),” Jurnal Hukum Adigama 1, no. 1 (2018): 1-22, https://doi.org/10.24912/adigama.v1i1.2147.

${ }^{22}$ Noer H and Mulati.

${ }^{23}$ Listianingsih, Mangundihardjo, and Prihatini, "Urgensi Pengaturan Terhadap Pengangkatan Anak Oleh Orang Tua Tunggal (Single Parents Adoption: Studi Kasus Penetapan No. 1/PDT.P/2010.PN.KGN Dan Penetapan No. 180/PDT.P/2012/PN.DPK."

${ }^{24}$ Dyah Permata Budi Asri, "Perlindungan Hukum Preventif Terhadap Ekspresi Budaya Tradisional Di Daerah Istimewa Yogyakarta Berdasarkan Undang-Undang Nomor 28 Tahun 2014 Tentang Hak Cipta,” JIPRO: Journal of Intellectual Property 1, no. 1 (2018): 13-23, https://journal.uii.ac.id/JIPRO/article/view/11142.
} 
adoption is in the best interests, welfare, and protection of the child. This is supported by Article 33 paragraph (1) letter $\mathrm{j}$ of the Regulation of the Minister of Social Affairs Number 110/HUK/2009 concerning Requirements for Adoption of Children, which stipulates the administrative requirements of prospective foster parents. Article 31 letter b stipulated that a statement would treat adopted children and biological children without discrimination, following the rights and needs of children on paper with stamps. This written statement is proof of the adoptive parents' abilities to ensure the welfare and protection of the child and the fulfilment of the child's rights and needs. When there are violations of the adopted child's rights, this written statement provides a filter and the basis for granting adoption applications. The statement, which is used as an administrative requirement for an adoption application, could be used as evidence when the adoptive parents do not comply with the written statement.

In addition, it is regulated in Article 26 of Government Regulation Number 54 of 2007 concerning Child Adoption regarding guidance in the implementation of child adoption by the Government and the community through outreach, consultation, counselling, mentoring, and training activities. Article 30 paragraph (2) of Government Regulation Number 54 of 2007 concerning Child Adoption stipulates that mentoring, as referred to in paragraph (1), aims first to examine and analyse applications for child adoption, and secondly to monitor the development of children in the care of adoptive parents. Countermeasures are carried out by ensuring the prospective adoptive parents' abilities to fulfil requirements. Article 26 of Government Regulation Number 54 of 2007 concerning Child Adoption in conjunction with article 30 paragraph (2) of Government Regulation Number 54 of 2007 concerning Child Adoption reduce the possibility in the future there is a violation of the child's rights in the adoption of a child by a single parent.

Article 32 letter $\mathrm{j}$ of the Minister of Social Affairs Regulation Number 110/HUK/2009 concerning Child Adoption Requirement stipulates other preventive legal protection. This Article regulates the material requirements of prospective foster parents, including having taken care of a prospective adopted child for a minimum of 6 (six) months since the parenting permit was granted. There are guidance and supervision from Social Workers during temporary parenting permit as stipulated in Article 34 paragraph (1) letter e of the Regulation of the Minister of Social Affairs Number 110/HUK/2009 concerning Requirements for Adoption of Children. Permit observation is regulated in Article 34 paragraph (1) letter g of the Regulation of the Minister of Social Affairs Number 110/HUK/2009 concerning Requirements for Adoption of Children through Home Visits by Social Workers of the Ministry of Social Affairs and Child Care Institutions. These home visits aim to find out the actual situation of the prospective adopted child. In addition, Article 35 stipulates that the Government and the community observe the implementation of child adoption. Article 39 of Government Regulation Number 54 of 2007 concerning Adoption of Children stipulates that Social Workers submit social reports regarding the eligibility of adoptive parents and child development in the care of adoptive parents' families to the minister or the head of the local social agency.

The regulation concerning the adoption of children by a single parent, especially Government Regulation Number 54 of 2007 concerning Child Adoption and Minister of Social Affairs Regulation Number 110/HUK/2009 concerning Requirements for Child Adoption, does not regulate sanctions for violations of children's rights in the adopting children by a single parent. Article 1 point 2 of Government Regulation Number 54 of 2007 concerning Adoption of Children and Regulation of the Minister of Social Affairs Number 110/HUK/2009 concerning Requirements for Adoption of Children stated that adoption is a legal act that diverts a child from the sphere of authority of parents, legal guardians or another person who is responsible for the child's care, education, and rearing to the adoptive parents' family environment. In this sense, it could be seen that parents should carry out some responsibilities or obligations in adopting children. Still, these obligations or responsibilities are not balanced 
with sanctions if these are violated. This causes much smuggling of laws and violations of obligations or responsibilities because there are no sanctions. ${ }^{25}$ The legality of sanctions is a guarantee that someone obeys a rule. ${ }^{26}$

The same applies to the lawsuit for the cancellation of adoption by a single parent, which is not regulated. Still, some regulated administrative obligations and conditions should be fulfilled. The legal substance includes two things which are orders and prohibitions. Thus, there are sanctions for violations. Unfortunately, there are no sanctions in the rules related to child adoption, so legal remedies that could be taken are like legal remedies against court decisions in general. Court decisions are the first and last decisions so that an appeal could not be made against the decision. Because the court's decision could not be appealed, the legal remedy is cassation under Article 43 paragraph (1) of Law Number 14 of 1985 concerning the Supreme Court. $^{27}$

Based on this description, regulating a single parent's child adoption is necessary. Furthermore, child adoption, especially by a single parent, is becoming more common in Indonesia. Therefore, the lack of unification and regulation regarding child adoption by a single parent with the weakness of law enforcement on the implementation of single parent adoption has formed the occurrence of legal smuggling of single parent adoption implementation. This is an urgent need to create legal certainty for the protection and welfare of neglected children in Indonesia. ${ }^{28}$

\section{Conclusion}

According to Government Regulation Number 54 of 2007, Adoption could be carried out by married couples and non-married person/single parent. This regulation is reinforced by the issuance of Circular Letter of the Supreme Court (SEMA) Number 6 of 1983 explaining that Indonesian citizens who are unmarried, have been married, or a single parent may adopt a child. In adopting a child by a single parent, it should meet the requirements of the provisions of Article 16 of Government Regulation Number 54 of 2007 concerning the Implementation of Child Adoption and Article 6 of the Regulation of the Minister of Social Affairs of the Republic of Indonesia Number 110/HUK/2009 concerning Requirements for Child Adoption. If it has fulfilled the requirements, the application could be submitted to Child Care Institutions to permit the Minister of Social Affairs or the Head of Provincial Social Agencies. After obtaining permission, the permit should be submitted to the court by registering an adoption application to obtain a stipulation of the court which could be used as legal evidence that the adopted child has been legally adopted by law.

\section{REFERENCES}

Amruzi, M. Fahmi Al. “Anak Angkat Di Persimpangan Hukum.” Masalah-Masalah Hukum 43, no. 1 (2014): 107-14. https://doi.org/10.14710/mmh.43.1.2014.107-114.

Anindia, Islamia Ayu. "Perlindungan Hukum Terhadap Perdagangan Anak Dengan Modus Pernikahan Dalam Perspektif Viktimologis.” Jurnal Litigasi 19, no. 1 (2018): 89-115.

\footnotetext{
${ }^{25}$ Usanti and Anand, Hukum Keluarga Dan Harta Benda Perkawinan.

${ }^{26}$ Peter Mahmud Marzuki, Pengantar Ilmu Hukum (Jakarta: Prenadamedia Group, 2018): 61.

27 Sovia Hasanah, "Upaya Hukum Terhadap Penetapan Pengadilan," HukumOnline.com, 2017, https://www.hukumonline.com/klinik/detail/ulasan/lt591a552ec941d/upaya-hukum-terhadap-penetapanpengadilan/.

${ }^{28}$ Listianingsih, Mangundihardjo, and Prihatini, "Urgensi Pengaturan Terhadap Pengangkatan Anak Oleh Orang Tua Tunggal (Single Parents Adoption: Studi Kasus Penetapan No. 1/PDT.P/2010.PN.KGN Dan Penetapan No. 180/PDT.P/2012/PN.DPK."
} 
https://doi.org/10.23969/litigasi.v19i1.776.

Asri, Dyah Permata Budi. "Perlindungan Hukum Preventif Terhadap Ekspresi Budaya Tradisional Di Daerah Istimewa Yogyakarta Berdasarkan Undang-Undang Nomor 28 Tahun 2014 Tentang Hak Cipta." JIPRO: Journal of Intellectual Property 1, no. 1 (2018): 13-23. https://journal.uii.ac.id/JIPRO/article/view/11142.

Bakarbessy, Leonora, and Dian Purnama Anugerah. "Implementation of the Best Interests of the Child Principles in Intercountry Adoption in Indonesia." Yuridika 33, no. 1 (2018): 7392. https://doi.org/10.20473/ydk.v33i1.7202.

Danjuma, Ibrahim, and Karatu Afabwaje Joel. "The Legal Conundrum in the Implementation of the Conventionon on the Rights of the Child in Nigeria." Sriwijaya Law Review 5, no. 1 (2021): 1-13. https://doi.org/10.28946/slrev.Vol5.Iss1.603.pp1-13.

DeJong, Margaret, Jill Hodges, and Osman Malik. "Children After Adoption: Exploring Their Psychological Needs.” Clinical Child Psychology and Psychiatry 21, no. 4 (2015): 1-15. https://doi.org/10.1177/1359104515617519.

Faradz, Haedah. "Pengangkatan Anak Menurut Hukum Islam.” Jurnal Dinamika Hukum 9, no. 2 (2009): 153-59. https://doi.org/10.20884/1.jdh.2009.9.2.223.

Fransiska Maryl Agatha, I Ketut Widia, and I Ketut Sukadana. "Pengangkatan Anak Oleh Orang Tua Yang Berbeda Keyakinan Dengan Calon Anak Angkatnya." Jurnal Prefensi Hukum 1, no. 2 (2020): 16-20. https://doi.org/10.22225/jph.1.2.2391.16-20.

Hartaka, Condro Putri Dewi. "Akibat Hukum Dalam Pewarisan Dari Pelaksanaan Pengangkatan Anak Oleh Orang Tua Tunggal." Jurnal Preferensi Hukum 1, no. 2 (2020): 181-85. https://doi.org/10.22225/jph.1.2.2384.181-185.

Hasanah, Sovia. "Upaya Hukum Terhadap Penetapan Pengadilan.” HukumOnline.com, 2017. https://www.hukumonline.com/klinik/detail/ulasan/lt591a552ec941d/upaya-hukumterhadap-penetapan-pengadilan/.

Kamil, H. Ahmad, and H. M. Fauzan. Hukum Perlindungan Dan Pengangkatan Anak Di Indonesia. 1st ed. Jakarta: PT RajaGrafindo Persada, 2008: 1-472.

Lee, Samantha Bei-wen. "The Equal Right to Parent: Protecting the Rights of Gay and Lesbian, Poor, and Unmarried Parents." NYU Review of Law and Social Change 41, no. 4 (2018): 631-84. https://socialchangenyu.com/review/the-equal-right-to-parent-protecting-therights-of-gay-and-lesbian-poor-and-unmarried-parents/.

Listianingsih, Dessy Marliani, Surini Mangundihardjo, and Farida Prihatini. "Urgensi Pengaturan Terhadap Pengangkatan Anak Oleh Orang Tua Tunggal (Single Parents Adoption: Studi Kasus Penetapan No. 1/PDT.P/2010.PN.KGN Dan Penetapan No. 180/PDT.P/2012/PN.DPK." Jurnal Hukum Acara Perdata 6, no. 1 (2020): 17-34. https://doi.org/10.36913/jhaper.v6i1.99.

Marzuki, Peter Mahmud. Pengantar Ilmu Hukum. Jakarta: Prenadamedia Group, 2018: 61.

Mawardi, Didiek R. "Fungsi Hukum Dalam Kehidupan Masyarakat." Masalah-Masalah Hukum 44, no. 3 (2015): 275-83. https://doi.org/10.14710/mmh.44.3.2015.275-283.

Mys, and Ali. "Penetapan Adopsi Harus Disertai Akta Kelahiran Anak." HukumOnline.com, 
2009. https://www.hukumonline.com/berita/baca/hol21746/penetapan-adopsi-harusdisertai-akta-kelahiran-anak.

Noer H, Stanley, and Mulati. "Analisis Terhadap Peraturan Pemerintah No. 54 Tahun 2007 Tentang Pelaksanaan Pengangkatan Anak Ditinjau Dari Prinsip Non Diskriminasi Dalam Konvensi Hak Anak (Contoh Kasus Polwan Gagal Adopsi Anak Karena Terhalang Peraturan Pemerintah)." Jurnal Hukum Adigama 1, no. 1 (2018): 1-22. https://doi.org/10.24912/adigama.v1i1.2147.

Prawirohamidjojo, R. Soetojo, and Marthalena Pohan. Hukum Orang Dan Keluarga (Personen En Familie-Recht). Surabaya: Airlangga University Press, 2008: 5-6.

Simpson, Mark. "Social Rights, Child Rights, Discrimination and Devolution: Untangling the Web." Journal of Social Welfare and Family Law 40, no. 1 (2018): 3-20. https://doi.org/10.1080/09649069.2018.1414201.

Siregar, Yolanda Triana, and Meilanny Budiarti Santoso. "Adopsi Dalam Perspektif Pekerjaan Sosial.” Kumawula: Jurnal Pengabdian Kepada Masyarakat 1, no. 3 (2018): 202-18. https://doi.org/10.24198/kumawula.v1i3. 22676.

Tobing, Rudyanti Dorotea. "Prevention of Child Marriage Age in the Perspective of Human Rights." Sriwijaya Law Review 2, no. 1 (2018): 1-17. https://doi.org/10.28946/slrev.Vol2.Iss1.107.pp1-17.

Usanti, Trisadini Prasastinah, and Ghansham Anand. Hukum Keluarga Dan Harta Benda Perkawinan. Surabaya: CV Revka Prima Media, 2019: 159. 